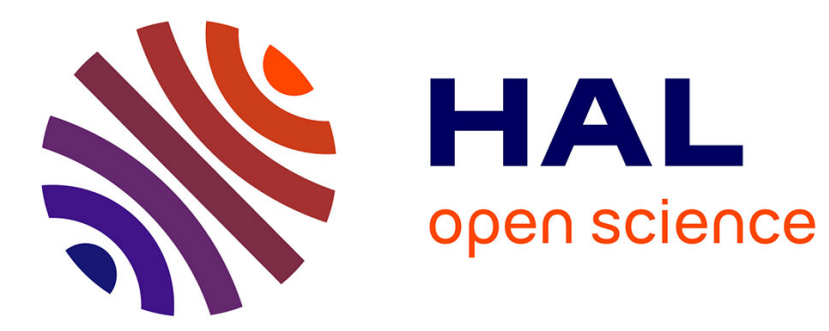

\title{
How to Design and Build New Musical Interfaces
}

Sidney Fels, Michael Lyons

\section{To cite this version:}

Sidney Fels, Michael Lyons. How to Design and Build New Musical Interfaces. 15th Human-Computer Interaction (INTERACT), Sep 2015, Bamberg, Germany. pp.642-643, 10.1007/978-3-319-227238_83. hal-01610833

\section{HAL Id: hal-01610833 \\ https://hal.inria.fr/hal-01610833}

Submitted on 5 Oct 2017

HAL is a multi-disciplinary open access archive for the deposit and dissemination of scientific research documents, whether they are published or not. The documents may come from teaching and research institutions in France or abroad, or from public or private research centers
L'archive ouverte pluridisciplinaire HAL, est destinée au dépôt et à la diffusion de documents scientifiques de niveau recherche, publiés ou non, émanant des établissements d'enseignement et de recherche français ou étrangers, des laboratoires publics ou privés. 


\title{
How to Design and Build New Musical Interfaces
}

\author{
Sidney Fels and Michael Lyons*
}

University of British Columbia and Ritsumeiken University

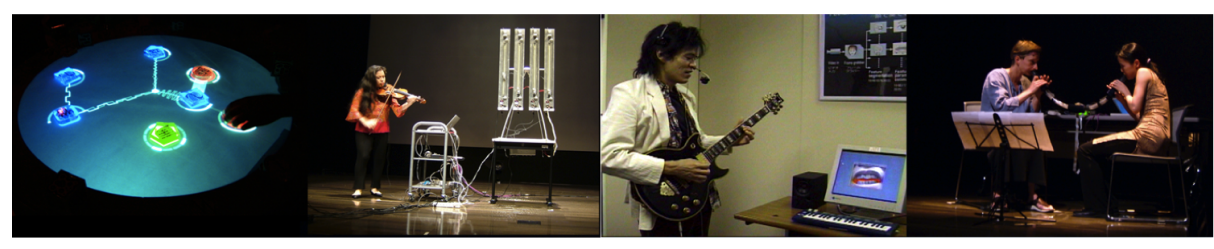

Fig. 1. Example Case Studies from the New Interfaces for Musical Expression (NIME) conference.

\begin{abstract}
This half day course introduces the field of musical interface design and implementation. Participants will learn and practice key aspects of the theory and practice of designing original interactive music technology with case studies including augmented and sensor based instruments, audio-visual instruments, mobile, and networked music making. Digital technologies offer powerful opportunities for the creation and manipulation of sound, however the flexibility of these technologies implies a confusing array of choices for musical composers and performers. Some artists have faced this challenge by using computers directly to create new musical forms. However, most would agree the computer is not a musical instrument, in the same sense as traditional instruments, and it is natural to ask 'how to play the computer' in a way appropriate to human brains and bodies. To attempt to answer this question in the course, we draw from the International Conference on New Interfaces for Musical Expression (NIME) [2,1], which began as a workshop of CHI 2001 [4] and explore connections with the established field of human-computer interaction abstract
\end{abstract}

Keywords: new interfaces for musical expression, digital musical instruments

\section{Learning Objectives and Structure}

The course learning objectives are: 1 . Provide a framework for understanding the current research on new musical interface technology; 2. Introduce the theory \&

\footnotetext{
* e-mail:ssfels@ece.ubc.ca;michael.lyons@gmail.com
} 
practice of NIME; 3. Point to further knowledge resources; 4. Get to know some of the people \& work of NIME; 5. Suggest how to begin creating new musical interfaces for a lifetime of challenge \& enjoyment. Participants will participate in a NIME design exercise.

The structure of the course is in two modules:

1. Module A : Introduction, Tools, Design: 1. Introduction; 2 Practical Guide to Building Musical Interfaces; 3. Video-based Interfaces; 4. Design and Aesthetics

2. Module B : Case studies, Theory, and Education: 1. Case studies; 2. Theory; 3. Education

3. Design Exercise

\section{Intended Audience}

Our primary objective in presenting this tutorial is to bring participants upto-speed on the application of interactive techniques to music technology. No specific technical background is required, though some familarity with interactive systems may be helpful. In particular, we do not assume any prior knowledge of sensors, microcontrollers, audio synthesis methods, but rather aim to provide participants with an introduction to these areas, as well as pointers to resources for further study. As such, the tutorial should be well suited to beginning graduate students or advanced undergraduates who are interested in this area of research; composers and performers who wish to expand their repertoire of methods and tools; member of the general public curious about recent developments and ongoing research in music technology.

\section{$3 \quad$ Reading list}

The course notes will be available for attendees to read prior to the course. Currently, a version of the notes can be found at: DOI: $10.1145 / 2659467.2659470$

\section{References}

1. Bevilacqua, F., Fels, S., Jensenius, A.R., Lyons, M.J., Schnell, N., Tanaka, A.: Sig nime: music, technology, and human-computer interaction. In: Extended Abstracts CHI'13. pp. 2529-2532. ACM (2013)

2. Fels, S., Lyons, M.: Interaction and music technology. In: Human-Computer Interaction-INTERACT 2011, pp. 691-692. Springer (2011)

3. Lyons, M., Fels, S.: Creating new interfaces for musical expression. In: SIGGRAPH Asia13 Courses. p. 17. ACM (2013)

4. Poupyrev, I., Lyons, M., Fels, S., Blaine, T.: New interfaces for musical expression. In: Extended Abstracts CHI'01. pp. 491-492. ACM Press (2001) 